\title{
Work Ethic across Generations in the Workplace
}

Effulgence

Vol. 19, No. 2

July - December, 2021

Rukmini Devi Institute of Advanced Studies

E-mail : effulgence@rdias.ac.in, Website : www.rdias.ac.in http://effulgence.rdias.ac.in/user/default.aspx https://dx.doi.org/10.33601/effulgence.rdias/v19/i2/2021/18-28

\author{
Andy Bertsch ${ }^{1}$ \\ Mohammad Saeed ${ }^{2}$ \\ James Ondracek ${ }^{1}$ \\ Mallory Sall ${ }^{1}$ \\ Zach Knipp ${ }^{1}$ \\ Tanner Gust ${ }^{1}$ \\ Courtney Gallagher ${ }^{1}$ \\ T.J. Martinez ${ }^{1}$ \\ Li Jisheng ${ }^{3}$
}

\begin{abstract}
The purpose: The purpose of this study is to understand how self-reported work ethic manifests across generations. We have explored three of the seven dimensions of work ethic as defined and operationalized by Miller et al., 2001, namely (1) hard work, (2) wasted time, and (3) centrality of work.
\end{abstract}

Design/Methodology/Approach: The research design is exploratory, using convenience sampling. The survey instrument of Multidimensional Measure of Work Ethic (MWEP) was adopted to evaluate work ethic across generations ranging from age 18 to 65. A total of 81 surveys were collected and analyzed. Quantitative analysis was performed with SPSS.

Findings: Baby Boomers and Generation X demonstrate a higher level of centrality of work as compared with the younger generations; and similarly, they have higher hard-working desire than the younger generations. In addition, the number of jobs could impose a significant influence over a person's level of hard work, wasted time and centrality of work.

Research Limitations: Sample size is small for each specific category. and this might affect the generalization of the survey results, without due caution. The dimensions, which were excluded, could be regarded as limiting boundaries of this study.

Managerial Implications: We have offered insights on work ethic across generations at the workplace. These should be useful to an organization, which focusses on the implications of employee behaviors to enhance the work efficiency and performance. It can be taken as reference for the stakeholders and management to design more conducive policies to uplift staff morale and work ethic. Lastly, it offers an avenue for future researchers to explore further the other dimensions of work ethic as a research phenomenon.

1. Minot State University, ND, USA.

2. Formerly Professor, Minot State University, ND, USA. saeed145@yahoo.com

3. Universiti Tun Abdul Razak, Malaysia. 
Originality/Value:This research is a further exploration on the research phenomena of work ethic through detailed exploration of its most significant dimensions. Across generational approach makes our endeavor distinctive from other studies on this theme.

Keywords: Work Ethic, Generations, HardWork, Wasted Time, Centrality of Work.

\section{INTRODUCTION}

Exploring Work Ethic Across Generations in The
Workplace

Lack of ethic and integrity can be detrimental to both the managers of organizations and society in general (Alkipsy, et al., 2020). Hill and Fotus (2005) believe that work ethic comprises of multiple characteristics, pertaining to attitudes, as each worker assigns importance and merit to his or her own work. Protestant work ethic (PWE) was first studied by Max Weber in 1905 (Weber, 1905). It suggests that protestant faiths share common ideologies that stress the value and importance of work (Miller et al., 2001). Although this had been later disproved, Weber's dimensions of work ethic would still be recognized as a pioneering manifestation (Yousef, et al., 2001). Early researchers emphasized a unidimensional construct of work ethic, when it was later deemed to be a multidimensional set of values (Miller, et al., 2001). Miller, et al., (2001) developed a Multidimensional Work Ethic Profile (MWEP). It incorporates seven dimensions of work ethic. We seek to investigate work ethic through these dimensions, which include leisure time, self-reliance, hard work, centrality of work, morality/ethics, delay of gratification, and wasted time (Miller, et al., 2001). For parsimony and to address our research questions, we focus on centrality of work, wasted time, and hard work. We will discuss this further in the literature review. There is agreement in the literature that MWEP is an accurate measure of work ethic. It is associated with Weber's original ideas, and also goes into greater detail on the various dimensions of work ethic (Van Ness, Melinsky, Buff, \& Seifert, 2010).
We investigated how self-reported work ethic manifests across generations. The demographics included in our study are age, gender, and number of jobs after the age of eighteen. We included age and gender because we believe that there are variances of work ethic across these variables. The number of jobs after eighteen should give us an idea of how many different workplaces someone has had; and if this attributes to self-reported work ethic. We understand that other factors such as environment, culture, or family life can affect someone's work ethic, but for the purpose of our study, we have investigated how work ethic differs across age and gender. Understanding factors that affect work ethic in different generations will help organizations to understand who is committed to the inherent value of work (Meriac, et al., 2009).

\section{Research Questions}

- What are the differences and similarities in selfreported work ethic across generations?

- What are the differences and similarities in selfreported work ethic by gender?

- Is there a relationship between number of jobs and degree of work ethic?

\section{LITERATURE REVIEW}

We seek to investigate work ethic across generations. Work ethic comprises of a set of characteristics as well as attitudes in which a worker assigns importance and merit to his or her own work. Panigrahi, , et al., (2019) posited that there has been growing evidence supporting the association between quality work ethic and job satisfaction of employees. Some believe that the decline in work ethic corresponds to lower levels of job performance, 
higher levels of absenteeism and turnover, and increases in counterproductive behavior ranging from unauthorized breaks to employee theft (Miller, et al., 2001). The seven dimensions of work ethic include self-reliance, hard work, centrality of work, morality/ethics, delay of gratification, and wasted time (Miller, et al., 2001). The three dimensions, chosen for our study, are hard work, centrality of work, and wasted time. There is an adequate support for our position, based on an objective and critical review of pertinent literature.

\section{Work Ethic}

The study by Salahudina, et al., (2016) concluded that work ethic affects job performance significantly; and is important from the standpoint of improving job performance. As the nature of work changes, the roles and behaviors of employees are in a state of flux (Meriac, et al., 2009). Organizations take interest in identifying employees, demonstrating high work ethic (Meriac, et al., 2009). Flynn (1994) found that $60 \%$ of managers ranked work ethic as the most important factor for decisions like hiring, promoting, and retaining administrative employees (Miller, et al., 2001). Work ethic was ranked higher $(60 \%)$ than employee characteristics such as intelligence $(23 \%)$, enthusiasm (12\%), and education (4\%) (Miller, et al.,2001). If an organization chooses to focus on work ethic, they will be able to build a workforce that will proactively pursue behaviors, which promote efficient practices of the organization over time, tasks, and situations (Meriac, et al., 2009). The assessment of work ethic has become increasingly important, as it allows administration to build and sustain a driven and concentrated labor force (Meriac, et al., 2009). Studies have evinced that work ethic is responsible for a nation's economic success or failure (Saks, et al., 1996).

Miller, et al., (2001) believe that the lack of attention in the literature may be due to the fact that previous studies reported equivocal results in the exploration of the relations of work ethic to organizationally relevant variables. Van Ness, et al., (2010) postulate that there is a dire need of empirical research into scientific theory of work ethic. Meriac, et al., (2010) believe that there is a difference in the dimensions of work ethic across Generation $z$, Millennials, Generation X, and Baby Boomers, but it may be contributed to respondents interpreting results in different ways. With this background of existing body of knowledge, we focused on identified dimensions of work ethic across generations.

\section{Hard work}

Different generations can view hard work varyingly. To an older generation that grew up working long days at the coal plant they consider that hard work, just the same as a software designer sits behind a computer working a long considers that hard work. Faithful involvement and commitment to work lead to decrease in unethical behavior like laziness, procrastination, or waste of time (Panigrahi, S., AlNashash, H. M., 2019)

One Generation $\mathrm{X}$ member was quoted as saying, “... integrity and character are the most important things to me. Being a team player is huge to me at all levels, hard worker, good work ethic -mainly just working hard, having good character, playing well with others, all those basic things" (Weeks, et al., 2016). This example gives an opinion of someone from generation $X$ and where they place the most emphasis as regards their work ethic. Hard work can be affected by cultural upbringings, but in this study we are just focused on work ethic across generations in the workplace. We felt the hard work dimension would be a great dimension to study and research because everyone in the workplace views hard work differently and there are so many different types of hard work.

\section{Centrality of work}

Volery, T. \& Tarabashkina, L. (2021) summarized that past research suggests that work centrality may act as a moderator influencing the work performance relationship between organizations and their 
employees. Managers should take initiatives, and support culture that would stimulate work centrality amongst the employees. Work centrality will strengthen creativity and motivate employees to make use of skills in order to engage in innovative behaviors. Centrality of work plays a key role in work ethic. Centrality of work is how important work is relative to the other interests in a person's life. People with this value are likely to plan their life around their job, and also be very focused on their work (Gursoy, et al., 2013). Work centrality is relevant to work ethic across generations because many of the upper-level positions are filled with baby boomers who tend to evaluate others on the level of importance they place on work. The different levels of importance may cause tension in the workplace if the different generations cannot see things from the other's perspectives (Gursoy, et al., 2013).

With technological improvements through the years, it has been easier to take your work home with you. It does not matter if your boss is traveling, if he/she needs to have a face-to-face talk with you, he/she can do that with a click of a mouse and an internet connection. That would make someone more likely to take their work home with them making their centrality of work higher. With these advances in technology, one would think the centrality of work has increased. However, this is not the case; centrality of work has become less important across the generations, and the Millennial generation shows the least amount of importance in regard to work centrality (Twenge \& Kasser, 2013).

There have been multiple studies done to review the centrality of work among generations, with varying results. Some early studies show that there is no difference among different career stages, whereas more recent studies show that the younger generations show less belief in work being a central part of life (Van Ness, et al., 2010). We feel this could be a product of younger generations placing more of an importance on their social life. Whatever the reasoning is, most of the generations do have one common need with regards to work centrality; while it seems, the younger generations show more importance to their leisure time over their work life, opposed to the older generations, all seem to show the need for improved work-life balance (Woodward, et al., 2015). No matter what level of importance is placed on work centrality, it is also important to correlate a good balance of work life and leisure time.

\section{Wasted Time}

Wasted time is an obvious obstacle for production. The list of things employees wastes their time on while working include office politics, interruptions from coworkers, interruptions from cell phones, tending to emails, and internet exploring (Zoupanou, et al., 2013). Kohnová, L. \& Salajová, N. (2018) studied the fresh graduates in their early years of employment; and found that the biggest time wasters for graduates differ from those time wasters that occur the most for employees in their later years of employment. These differences may come from different level of responsibility in the work for each group but also from the habits that graduates in their first years of employment are only learning. Studies have shown that employees have two to six hours of waste for every eight hours of work (Flinchbaugh, 2013). Metin, Taris, and Peeters (2016) show that 25\% of adults consider themselves to be procrastinators. For the purpose of our study, we will be using wasted time as one of our measurements (Miller, et al., 2001).

\section{Self-Reliance}

Self-reliance is how an individual takes care of his/ her work without the guidance of another (Van Ness, et al., 2010). There are studies that suggest the possibility of younger generations are more selfreliant, as they are aware of the changing environment, and latest developments. Cristiano, P. \& Pierce, I. (2020) highlighted that a high level of individual choice and self-reliance were encouraged in day-to-day project management. We decided to 
omit this from our study because there is a chance that younger generations will have a much higher self-reliance than the older generations. The younger generations show more enthusiasm over being selfreliant and making their own decisions. It also appears that the younger generations have a stronger desire to have a higher amount of responsibility; and make influential decisions while functioning all by themselves (Van Ness, et al., 2010).

\section{Leisure}

We chose not to include leisure time in our study, because we feel it is not a dimension of work ethic that is involved directly with the workplace, in a significant manner. We are studying generations and their work ethic in the workplace, leisure deals with what you do outside of the workplace. That is why we chose not to use it. Leisure is poised as a dimension of work ethic in some studies, but we concluded, based on our review of pertinent studies, that it does not really affect your work ethic in the working environment that we are more interested in (Van Ness, et al., 2010).

\section{Morality/Ethics}

Morality and Ethics refer to the manner in which people act or are expected to act. We decided to not focus on this dimension because there is a chance that people with more workforce experience will have a stronger set of morality and ethics. Morality and ethics are clearly influenced by career status, with workforce professionals demonstrating a stronger moral and ethical aptitude than college students (Van Ness, et al., 2010). With this information, we omitted Morality and Ethics in our study, because we feel that the generation that has been in the workforce longer would have a higher score in this category.

\section{Delay of Gratification}

It is the ability to forego short-term rewards in order to achieve a goal that provides long term gratification. We came to the decision to omit this dimension because we felt that individuals who are a part of the older generations have a higher chance to not be as tempted for short term rewards as one who is of the younger generation. Greater satisfaction with a commitment to an organization could be associated with an orientation toward or ability to delay gratification. Basically, the longer tenure with a company, the higher ability you have to delay gratification. With us focusing strictly on generations, delay of gratification is a dimension that is not as important. It would favor the older generations who have most likely been with their organizations longer, and therefore have a greater sense of delay of gratification(Witt, 1990).

\section{Generations}

We will be exploring the work ethic of four different generations: Generation Z, Baby Boomer, Generation $X$, and Millennials. Generational characteristics are defined by the difference in ideas, values, and behaviors. Ng, Schweitzer, and Lyons (2010) deem that the millennial generation hold values, attitudes, and expectations that are significantly different from the generations of workers that preceded them. Overall, the literature concludes differences between generations but has not specified these differences, which will be the centerpiece of our study.

\section{METHODOLOGY}

Our research design was exploratory in nature. Such designs allow for convenience sampling as, by definition, exploratory designs are investigating relationships (Bertsch, et al., 2017; Bertsch \& Pham, 2012). Our sample frame was a community in the upper Midwest of the United States.

We borrowed survey questions from the Multidimensional Measure of Work Ethic (MWEP) instrument. (Miller, et al., 2001). This instrument has been shown to be psychometrically sound. Exploratory Factor Analysis was completed during the development of the instrument and alpha values 
were excellent and were above 0.80 for all dimensions except two: Delay of Gratification and Wasted Time ( $\mathrm{a}=0.73$ and $\mathrm{a}=0.75$ respectively) (Miller, et al., 2001). Miller, et al., (2001) describe seven dimensions of work ethic which we expanded upon in our literature review: self-reliance, morality/ethics, leisure, hard work, centrality of work, wasted time, and delay of gratification. We added some basic demographic questions to help create the sampling necessary to answer our research questions.

We evaluated a multidimensional measure of work ethic across generations. (Miller, et al., 2001). The study included samples from multiple generations ranging from ages 18-65. Our targeted overall sample size was based on the 3:1 ratio described by Bertsch \& Pham (2012). Support of this rule of thumb is provided by Tande, Lamon, et al., (2013); and takes into consideration the arguments of large vs. small sample sizes (Hair, et al., 2010).

\section{ANALYSIS}

To prepare our data for analysis, we used scrubbing techniques provided by Bertsch \& Pham (2012), Croarkin (2011), Howell (2012), and Osborne \& Overbay (2004). This enabled identification of missing data and outliers. For the missing data we implemented mean substitution for that exact item. Once the data was properly prepared and scrubbed, we proceeded to analyze the data. In the end, we admit a limitation to our data collection; and resulting sample size for specific categories is considered small for quantitative analyses techniques. We decided to offer our findings while acknowledging this limitation.

\section{By Generation}

Generations were the focus on our studies. The following tables breakdown the differences amongst the generations that we surveyed.

Table 1. Generation Averages (ages at the time of data collection)

\begin{tabular}{|l|c|c|c|}
\hline & Hard Work & Wasted Time & Centrality of Work \\
\hline $\begin{array}{l}\text { Generation Z (18-21) } \\
\mathbf{n}=\mathbf{1 0}\end{array}$ & 3.72 & 3.54 & 3.38 \\
\hline $\begin{array}{l}\text { Millennials (22-40) } \\
\mathbf{n}=\mathbf{3 8}\end{array}$ & 3.89 & 3.56 & 3.74 \\
\hline $\begin{array}{l}\text { Generation X (41-52) } \\
\mathbf{n}=\mathbf{1 8}\end{array}$ & 3.95 & 3.83 & 4.07 \\
\hline $\begin{array}{l}\text { Baby Boomers (53<) } \\
\mathbf{n = 1 5}\end{array}$ & 4.04 & 3.77 & 3.92 \\
\hline
\end{tabular}

Table 2. Generation $\mathrm{Z}$ vs. remaining generations (significant differences or not?)

\begin{tabular}{|l|c|c|c|}
\hline & Hard work & Wasted Time & Centrality of Work \\
\hline Gen Z Vs. Millennials & Not Significant & Not Significant & $\mathrm{p}<0.05$ \\
\hline Gen Z Vs. Generation X & Not Significant & $\mathrm{p}<0.01$ & $\mathrm{p}<0.001$ \\
\hline Gen Z Vs. Baby Boomers & Not Significant & Not Significant & $\mathrm{p}<0.01$ \\
\hline
\end{tabular}


Table 3. Millennials vs. remaining generations (significant differences or not?)

\begin{tabular}{|l|c|c|c|}
\hline & Hard Work & Wasted Time & Centrality of Work \\
\hline $\begin{array}{l}\text { Millennials Vs. } \\
\text { Generation X }\end{array}$ & Not Significant & $\mathrm{p}<0.01$ & $\mathrm{p}<0.05$ \\
\hline $\begin{array}{l}\text { Millennials Vs. Baby } \\
\text { Boomers }\end{array}$ & Not Significant & Not Significant & Not Significant \\
\hline
\end{tabular}

Table 4. Generation $X$ vs. remaining generations (significant differences or not?)

\begin{tabular}{|l|c|c|c|}
\hline & Hard Work & Wasted Time & Centrality of Work \\
\hline Gen X Vs. Baby Boomers & Not Significant & Not Significant & Not Significant \\
\hline
\end{tabular}

We found no significant differences across any of the generations for the dimension of Hard Work. For the dimension of Wasted Time, Generation $X$ had the highest mean at 3.83 followed by Baby Boomers $(\mathrm{m}=3.77)$; Generation $\mathrm{Z}(\mathrm{m}=3.54)$ and Millennials $(\mathrm{m}=3.56)$. Gen $X$ averaged a significantly higher attitude toward Wasted Time when compared to Gen $Z$ and Millennials, both at $p<0.01$. There were no other significant differences across generations when analyzing Wasted Time.

The last dimension we analyzed was Centrality of Work where we found four significant differences across generations. Generation $X$ scored the highest on this dimension with a mean of 4.07. This was shown to be significantly higher than Millennials $(\mathrm{m}=3.74)$ at $\mathrm{p}<0.05$ and higher than Gen $\mathrm{Z}(\mathrm{m}=3.38)$ at $p<0.001$. There was no significant difference between Gen X and Boomers on this dimension. In addition to being significantly lower than Gen $X$, Gen Z's score of 3.38 was shown to be significantly lower than Millennials $(m=3.74)$ at $p<0.05$ and lower than Baby Boomers $(\mathrm{m}=3.92)$ at $\mathrm{p}<0.01$.

\section{By Gender}

Table 5 summarizes the comparisons by gender. For the construct of Wasted Time, we found that men $(m=3.70)$ scored significantly higher than women $(m=3.59)$ at $p<0.01$. For the dimensions of Hard Work and Centrality of Work, we found no significant differences by gender.

Table 5: Work Ethic Dimensions by gender

\begin{tabular}{|l|c|c|c|}
\hline & Hard Work & Centrality of Work & Wasted Time \\
\hline Male & 3.93 & 3.93 & 3.70 \\
\hline Female & 3.83 & 3.65 & 3.59 \\
\hline Significance & None & None & $\mathrm{p}<0.01$ \\
\hline
\end{tabular}


Table 6 shows the analysis based on the number of jobs an individual has and his/ her work ethic. We categorized the data based on groupings labeled "Number of jobs 1-3"; "Number of jobs 4-6" and "Number of jobs 6+". Comparing "Number of jobs 13 " vs. "Number of jobs 4-6" resulted in significant differences in every work ethic category with those having held more jobs scoring higher than those having held fewer jobs. Comparing "Numbers of jobs 1-3" vs. "Number of jobs $6+$ " resulted in only one significant difference with those holding more than six jobs reporting a higher mean score. We found no significant differences when analyzing "Numbers of jobs 4-6" vs "Number of job 6+" across the three dimensions.

Table 6: Work Ethic Dimensions by Number of Jobs After the Age of 18

Number of Jobs 1-3 Vs. Number of Jobs 4-6

\begin{tabular}{|c|c|c|c|}
\hline & Hard Work & Wasted Time & Centrality of Work \\
\hline Number of Jobs 1-3 & 3.61 & 3.53 & 3.61 \\
\hline Number of Jobs 4-6 & 4.03 & 3.77 & 3.88 \\
\hline Significance & $\mathrm{p}<0.001$ & $\mathrm{p}<0.05$ & $\mathrm{p}<0.05$ \\
\hline
\end{tabular}

Number of Jobs 1-3 Vs. Number of Jobs 6+

\begin{tabular}{|c|c|c|c|}
\hline & Hard Work & Wasted Time & Centrality of Work \\
\hline Number of Jobs 1-3 & 3.61 & 3.53 & 3.61 \\
\hline Number of Jobs 6+ & 3.99 & 3.57 & 3.74 \\
\hline Significance & $\mathrm{p}<0.05$ & None & None \\
\hline
\end{tabular}

Number of Jobs 4-6 Vs. Number of Jobs 6+

\begin{tabular}{|c|c|c|c|}
\hline & Hard Work & Wasted Time & Centrality of Work \\
\hline Number of Jobs 4-6 & 4.03 & 3.77 & 3.88 \\
\hline Number of Jobs 6+ & 3.99 & 3.57 & 3.74 \\
\hline Significance & None & None & None \\
\hline
\end{tabular}

\section{DISCUSSION}

We sought to answer three research questions. These questions are: 1) What are the differences and similarities in self-reported work ethic across generations? 2) What are the differences and similarities in self-reported work ethic by gender? 3) Is there a similarity between number of jobs and degree of work ethic?

To answer the first question, we found that Gen $X$ tied with the Baby Boomers for the lead in hard work with an average of 4.00 , but they led in the two other categories scoring a 3.8 in wasted time, and 4.0 in centrality of work. Millennials scored a 3.8 in hard work whereas Gen $Z$ came in last scoring a 3.7. Gen $\mathrm{Z}$ and Millennials tied with a 3.5 under wasted time, and Baby Boomers came in last with a score of 3 . Under centrality of work, Baby Boomers were 2nd with a score of 3.9, Millennials were 3rd with a 3.7, and Gen $\mathrm{Z}$ was last with a score of 3.3. Looking at all these numbers, we can conclude that Gen $Z$ vs. Gen $X$ had a significance of $\mathrm{P}<.01$ in wasted time and $\mathrm{P}<.001$ in centrality of hard work. Gen $\mathrm{Z}$ vs. 
Millennials had a significance of $\mathrm{P}<.05$ in centrality of hard work. Gen Z vs. Baby Boomers had a significance of $\mathrm{P}<.01$ under centrality of hard work. Millennials vs. Gen $X$ had a significance of $P<.01$ in wasted time and $\mathrm{P}<.05$ in centrality of hard work. All the remaining generation work ethic comparisons had no significance, worth triggering.

The second question we wanted to answer was, what are the differences and similarities in selfreported work ethic by gender? Females scored higher under all three categories than the males. Hard work, wasted time, and centrality of work scored 3.9, 3.7, and 3.9 respectively. Men scored 3.8 in hard work, and 3.6 in wasted time, and 3.6 in centrality of hard work. From these numbers, we can conclude that Females vs. Males had a significance of $\mathrm{P}<.01$ under wasted time. All remaining gender work ethic comparisons had no significance.

Our third and last question was, is there a similarity between number of jobs and degree of work ethic? We broke number of jobs down into three categories, 1-3, 4-6, and 6+. Category 4-6 and 6+ had the highest hard work, scoring 4.0 for both. Category 1-3 was the lowest, scoring 3.6 in hard work. All categories scored different in wasted time. 1-3 was 3 rd with a score of $3.5,6+$ was 2 nd with a score of 3.6, and 4-6 was first with a score of 3.8 under wasted time. Centrality of hard work had similar standings. 1-3 was 3 rd with a score of $3.6,6+$ was second with a score of 3.7, and 4-6 was first with a score of 3.9 under centrality of hard work. With these numbers, we can conclude that category 1-3 had a significance of $\mathrm{P}<.001$ in hard work, a significance of $\mathrm{P}<.05$ in wasted time, and a significance of $\mathrm{P}<.05$ in centrality of hard work. Category 1-3 had significance in all three topics. Category 4-6 had a significance of $\mathrm{P}<.05$ in hard work. All remaining category work ethic comparisons had no significances.

According to the literature, older generations tend to have a higher score in centrality of work than younger generations. We found this to be true in our study. Generation $\mathrm{Z}$ (the youngest) scored the lowest in centrality of work, whereas the Baby Boomers and Generation X (the two oldest) scored the highest. This can conclude what the past researchers have said about younger generations not considering their work life to be as important as their life outside of work. We also found the theory that older generations score higher in hard work to be true as well. From Generation $\mathrm{Z}$ to Baby Boomers, the score increases with age $(3.7,3.8,4.0,4.0)$. Hence, we can conclude that older generations have a higher hardworking desire than the younger generations. Past researchers have suggested that careers do not play a role in a person's hard work. According to our study, we found this to be false. People with 1-3 jobs after the age of 18 scored lower than the people who had anything above 4 . Our study found that more jobs influence a person's hard work. This was not the case for other two topics, as centrality of work and wasted time fluctuated with the increase in number of jobs past, the age of 18 .

\section{IMPLICATIONS OF THE STUDY}

The study offers insights on work ethic across generations at the workplace; and is therefore useful to the organizations, which wish to focus on significant differences to customize and personalize the interactive activities and communications with the staff. This would ultimately facilitate the process of enhancing the work efficiency and performance at the workplace. Secondly, the results of this study can be taken as reference for those stakeholders and management to devise more conducive policies to uplift staff morale and work ethic. Lastly, it offers opportunities for future researchers to explore further the other dimensions of work ethic as a research phenomenon.

\section{CONCLUSION}

This study explored in detail the three (3) dimensions of the work ethic, namely Hard Work, Wasted Time and Centrality of Work through a cross-generational approach. The survey instrument of Multidimensional Measure of Work Ethic 
(MWEP) was adopted to evaluate work ethic across generations ranging from age 18 to 65 . As a conclusion, this research found that older generations tend to have a higher level of centrality of work as compared with the younger generations. They demonstrate higher hard-working desire than that by the younger generations. This study also found that the number of jobs could impose a significant influence over a person's level of hard work, wasted time and centrality of work. This result of this study would be of importance for the leadership and stakeholders of the organizations to devise more effective polices and activities to uplift the work ethic across all generations at the workplace. In addition, it offers an avenue for the future researchers to continue exploring the research phenomenon of work ethic.

\section{REFERENCES}

Alkipsy, E. I. \& Raju, V. (2020). Mediation Role of Work Ethics between Transformational, Transactional and Participative Leadership Styles and Managerial Efficiency: A Review of Literature The Mattingley Publishing Co., Inc, ISSN: 0193-4120,13248 - 13258.

Bertsch, A., Pham, L. (2012) A Guide to Research Design and Multivariate Analysis in Cross Cultural Research, Journal of International Doctoral Research, Vol 1(1).

Bertsch, A., Nguyen, HTH, Alford, A., Baran, W., Reynen, J., Saeed, M., Ondracek, J. (2017) Exploring the relationship between personality and preferred leadership, Journal of Leadership, Accountability, and Ethics, 14(1), p.32-45

Cristiano, P. \& Pierce, I. (2020) Inspiring a SelfReliant Learning Culture while Brewing the Next Silicon Valley in North Wales. MDPI: Education Sciences, 1-12.

Croarkin, C. (2011). Engineering statistics handbook. Retrieved from http://www.itl.nist.gov/div898/handbook/prc / section1/prc16.htm

Flynn, G. (1994). Attitude more valued than ability. Personnel Journal, 73, 16.
Gursoy, D., Chi, C. G., \& Karadag, E. (2013). Generational differences in work values and attitudes among frontline and service contact employees. International Journal of Hospitality Management, 32, 40-48.

Hair, J. F., JR., Babin, B., Money, A. H. \& Samouel, P. (2010) Essentials of Business Research Methods, New Jersey, Wiley.

Hill, R. B., \& Fouts, S. (2005). Work ethic and employment status: a study of job seekers. Journal of Industrial Teacher Education, 42(3). Retrieved from http:/ / scholar.lib.vt.edu/ejournals/JITE/v42n3 /hill.html

Howell, D. (2012, December 9). Treatment of missing data. Retrieved from http://www.uvm.edu/ dhowell/StatPages/M ore_Stuff/Missing_Data/Missing.html

Kelly Pledger Weeks, Caitlin Neese, \& Caitlin McLysaght (2016) Generational Difference At Work: Have We Missed Something? 173-184

Meriac, J., Poling, T., Woehr, D. (2009). Are there Gender Differences in Work Ethic? An Examination of the Measurement Equivalence of the Multidimensional Work Ethic Profile. Elsivier Journal. 210

Meriac, J., Woehr, D., \& Banister, C., (2010). Generational Differences in Work Ethic: An Examination of Measurement Equivalence Across Three Cohorts. Journal of Business Psychology.

Miller, M., Woehr, D., \& Hudspeth, N. (2001). The meaning and measurement of work ethic: Construction and initial validation of a multidimensional inventory. Journal of Vocational Behavior, 59, 1-39.

Ng, E., Schweitzer, L., \& Lyons, S. (2010). New Generation, Great Expectations: A Field Study of the Millennial Generation. Journal of Business and Psychology

Osborne, J.W., \& Overbay, A. (2004). The power of outliers (and why researchers should always check for them). Practical Assessment, Research \& Evaluation, 9(6). Retrieved from 
http:/ /PAREonline.net/getvn.asp?v=9\&n=6

Panigrahi, S., Al-Nashash, H. M. (2019). Quality Work Ethics and Job Satisfaction: An Empirical Analysis (2019). QUALITY Access to Success. Vol. 20, No. 168.

Salahudina, S. N., Alwia, M. N. R., Baharuddina, S. S. (2016). The Relationship between Work Ethic and Job Performance. The European Proceedings of Social \& Behavioral Sciences. 3rd International Conference on Business and Economics.

Saks, A., Mudrack, P., \& Asforth B., (1996). The Relationship Between the Work Ethic, Job Attitudes, Intention to Quit and Turnover for Temporary Service Employees. Revue Canadienne des Sciences de l'Administration.

Tande, B., Lamon, K., Harstad, C., Ondracek, J., \& Bertsch, A. (2013). An empirical investigation into similarities and differences in communication of female and male students at a US university. Journal of International Doctoral Research, 2(1), 78-114.

Twenge, J. M., \& Kasser, T. (2013). Generational Changes in Materialism and Work Centrality, 1976-2007 Associations With Temporal Changes in Societal Insecurity and Materialistic Role Modeling. Personality and Social Psychology Bulletin, 39, 883-897.

Van Ness, R., Melinsky, K., Buff, C., \& Seifert, C. (2010). Work ethic: Do new employees mean new work values?. Journal of Managerial Issues, 22(1), 10-34.

Volery, T. \& Tarabashkina, L. (2021). The Impact of Organizational Support, Employee Creativity and Work 2 Centrality on Innovative Work Behavior. Journal of Business Research, Vol. 129, 2021, pp. 295-303

Woodward, I. C., Vongswasdi, P., \& More, E. A. (2015). Generational Diversity at Work: A Systematic Review of the Research. SSRN Electronic Journal. Retrieved from https:// sites.insead.edu/facultyresearch/resear ch/ doc.cfm?did=56531

Weber, M. (1905). The Protestant Ethic and the Spirit of Capitalism. Scribners: New York.

Witt, L. 1990. “Delay of Gratification and Locus of
Control as Predictors of Organizational Satisfaction and Commitment: Sex Differences." The Journal of General Psychology 117 (4): 437446

Yousef, D. (2001). Islamic work ethic - A moderator between organizational commitment and job satisfaction in a cross-cultural context. Retrieved from http://www.angelfire.com/nd/aminz/ ethics/Islamic_work_ethic.htm

Zoupanou, Z., Cropley. M, Rydstedt, LW. (2013). Recovery after Work: The Role of Work Beliefs in the Unwinding Process. PLOS One. 1-9. 